\title{
The Cold War on Film: Then and Now
}

\section{Introduction}

Tony Shaw and Sergei Kudryashov

A focus on culture has been one of the major innovations in the study of the Cold War over the past two decades. This has helped historians and the general public to view the Cold War as a conflict of ideas and images as well as bullets and bombs. Film is thought to have played a particularly important role throughout the Cold War. Scholars now recognise that cinema was a powerful vehicle of entertainment and propaganda, one that, among other things, showed audiences the 'reality' of what was for many people a peculiarly abstract conflict. As a result, today school and university courses about the Cold War regularly incorporate clips from movies like Stanley Kubrick's anti-nuclear black comedy Dr Strangelove (1964) and Sylvester Stallone's feverishly anti-communist sports drama Rocky IV (1985).

Up to now, most scholarly work on the relationship between the Cold War and cinema has focused on Hollywood. This is understandable given the headlines that the witch-hunt of leftists in Hollywood attracted during the McCarthy era, the sheer number of movies related to the Cold War that Hollywood produced, and the global reach of the American film industry during the conflict. Nonetheless, this American-centric approach has tended to skew the picture overall, leaving some with the impression that 
Hollywood was subjected to unique political pressures during the Cold War and that the American film industry won the cinematic Cold War almost by default.

In September 2014, an international conference was held at the German Historical Institute in Moscow, Russia on the subject of 'The Cold War on Film: Then and Now'. The conference had three main objectives. First of all, the conference sought to take stock of what we now know about the role played by the American film industry during the Cold War. Participants addressed this issue from several different angles, including exploring how Hollywood movies helped militarise America's suburban landscape after the Second World War, reassessing Hollywood liberals' resistance to the Congressional House Un-American Activities Committee in the 1940s and 1950s, and outlining the interconnections between rock music, documentary-making and nuclear politics in the 1970s and 1980s.

Secondly, the conference aimed to put Hollywood's 'performance' in an international, comparative context. The conference therefore looked beyond Hollywood and sought to explore how cinemas from different regions of the world - East, West, North and South - both dealt with and were affected by the Cold War. In this respect, discussion centred on several key questions, including: Is it possible to identify a range of important players in the cinematic Cold War? What are the similarities and differences between the ways that national film industries framed the Cold War? Which film industries gained from the Cold War and which lost? What was distinctive about cinema's contribution to the Cold War? What does a comparative analysis of Cold War cinema tell us about the uses of propaganda during the conflict and about the Cultural Cold War more generally? 
The conference's third major aim was to explore how filmmakers had dealt with the Cold War since the conflict had ended. A great deal has been written about how filmmakers 'remade' the Second World War in the 1950s and 1960s and how their movies might have influenced wider beliefs about that conflict. The Moscow conference sought to find out whether and if so how filmmakers had done the same with the Cold War. Papers began the process of mapping out how cinema had replayed or refought the Cold War over the past quarter of a century. It also considered the potential impact of the resulting narratives and images on public perceptions of the Cold War. Important questions in this regard included: How prominent a subject has the Cold War been on cinema screens since 1989? Which national cinemas have paid the Cold War most attention, how and why? Conversely, which cinemas have effectively airbrushed the Cold War and why? What roles have governments or other organisations played in reworking the Cold War on the big screen? How has cinema presented the Cold War as history?

This issue of the Historical Journal of Film, Radio and Television incorporates a representative cross-section of papers delivered at the September 2014 Moscow conference. The six articles do not provide answers to each and every question raised above. They focus, instead, on a number of film genres and seminal Cold War themes and draw on international, historical and contemporary perspectives. Combined, the articles offer useful insights into the transnational dimensions of the cinematic Cold War, the close interplay between film and cultural diplomacy (or soft power) during the conflict, and how filmmakers since the fall of the Berlin Wall have seen the Cold War as a fertile source for profit. 
Paul McGarr starts us off by looking at a subject which Cold War scholars and film historians have so far almost entirely overlooked, Soviet-Indian film exchange. McGarr tells us that Indian movies were a prominent feature of cultural life behind the Iron Curtain and traces that little-known phenomenon to the 1950s. His tightly-argued, blow-by-blow account of Indian-Soviet negotiations over a Hindi social drama, Rahi, not only illuminates the political ground rules that governed bilateral Indo-Soviet cinematic interchange during the Cold War. It also points to the value of bringing diplomatic documentation to the table when writing about Cold War culture. The next article, by Andrei Kozovoi, stays with the subject of international film exchange but switches attention to Soviet-US relations in this sphere. Kozovoi utilises Soviet documents to reveal the complex political, ideological and economic dynamics of superpower film diplomacy during the period when Nikita Khrushchev held office in the Kremlin. As such, Kozovoi adds to the literature on the so-called cultural Thaw that the USSR experienced after the death of Josef Stalin and, more importantly perhaps, shows us how difficult it was for the American and Soviet film industries to talk with each other even during periods of détente.

James Deutsch's article takes a fresh look at a classic subject, Kubrick's Dr. Strangelove. Like Kozovoi, Deutsch draws on hitherto little-used documentation, in his case to analyse what European communists on both sides of the Iron Curtain made of Dr. Strangelove. He shows us that, contrary to the fears of many American critics, Kubrick's movie by and large did not generate increased hostility towards the United States' defence and foreign policies. Many communist critics instead read $\mathrm{Dr}$. Strangelove either as a warning to both East and West of the dangers posed by the spiralling nuclear arms race or as a brilliant piece of filmmaking. Many of the films that 
Mick Broderick then examines in his article on Australian and New Zealand nuclear cinema during and beyond the Cold War were not nearly as influential as $D r$.

Strangelove. Yet these films demonstrate powerfully how national cinemas could take distinctive approaches to controversial subjects like nuclear weapons, thereby making those subjects directly relevant to their citizens. Broderick points to the Mad Max series to show us that Antipodean 'cinematic nuclearism' continues to make international political and cultural waves today.

Kumuthan Maderya's article introduces us to another aspect of Cold War cinema that few scholars have explored to date, Tamil Indian agitprop films of the 1980s. These mostly avant-garde art films appropriated Cold War paradigms to stage the struggles of the Indian working classes against local capitalists and often valorised bloody revolution as the only means for the poor to gain power. Maderya demonstrates that the Cold War battle for hearts and minds was truly global in nature and influenced cultural production in regions far away from direct superpower confrontation. Finally, Eric Morgan's article brings us through the present day by examining the Swede Tomas Alfredson's 2011 acclaimed Cold War spy movie, Tinker Tailor Soldier Spy. Morgan compares Alfredson's film with Martin Ritt's classic spy thriller from 1965, The Spy Who Came in from the Cold, in order to assess how John le Carre's novels have been used as cinematic critiques of espionage tradecraft for several decades. In the process, Morgan shows us how today's depictions of the Cold War on screen reflect the public's sense of nostalgia about the conflict on the one hand and profound doubts about the accountability of modern-day intelligence services on the other.

All of these contributions attest to the richly varied nature of the cinematic Cold War and how studies of film during the Cold War must integrate, among other things, 
geographical, ideological, cultural, political and economic factors. Beyond the arguments posed within each individual contribution, these articles collectively offer a broader understanding of why and how film affirmed and challenged prevailing political views during the Cold War. Our chief hope is that this issue will encourage scholars to explore how cinema, television, novels, plays and so on have treated the subject of the Cold War since the conflict died and passed into history. As the $30^{\text {th }}$ anniversary of the fall of the Berlin Wall fast approaches, it seems high time we should reflect on what the Cold War now means to people and on the role the mass media has played in forging those meanings.

Tony Shaw is Professor of Contemporary History at the University of Hertfordshire. His publications include Hollywood's Cold War (University of Massachusetts Press, 2007) and, with Denise J. Youngblood, Cinematic Cold War: The American and Soviet Struggle for Hearts and Minds (University Press of Kansas, 2010). His latest book is Cinematic Terror: A Global History of Terrorism on Film (Bloomsbury, 2015). a.t.shaw@herts.ac.uk

Sergei Kudryashov is a scientific researcher (Mitarbeiter) at the German Historical Institute in Moscow. He studied history at the Russian Academy of Sciences, and has published widely on the Second World War and Soviet history. sergey.kudryashov@dhi$\underline{\text { moskau.de }}$ 